\title{
Hematological Alterations Induced by Imidacloprid and Ameliorative Effect of Withania somnifera in Female Albino Wistar Rats
}

\author{
S. Soujanya ${ }^{1 *}$, M. Lakshman ${ }^{1}$, D. Madhuri ${ }^{1}$, A. Gopala Reddy ${ }^{2}$ and S.V. Rama Rao ${ }^{3}$ \\ ${ }^{1}$ Department of Veterinary Pathology, College of Veterinary Science, PVNRTVU, Rajendranagar, Hyderabad, INDIA \\ ${ }^{2}$ Department of Veterinary Pharmacology and Toxicology, College of Veterinary Science, PVNRTVU, Rajendranagar, \\ Hyderabad, INDIA \\ ${ }^{3}$ Department of Avian Nutrition, Directorate of Poultry Research, Rajendranagar, Hyderabad, INDIA \\ *Corresponding author: S Soujanya; E-mail: sonurv36@gmail.com
}

Received: 07 March, 2020

Revised: 03 April, 2020

Accepted: 04 April, 2020

\begin{abstract}
Present study was aimed to evaluate the effect of oral administration of imidacloprid on weekly body weights and hematological parameters in female rats and also to determine the protective role of Withania somnifera against imidacloprid induced toxicity. Forty eight (48) female albino Wistar rats were divided into four (4) groups of twelve (12) animals each. Group 1 served as control, groups 2 was given with imidacloprid at the rate of $30 \mathrm{mg} / \mathrm{kg} \mathrm{b}$.wt/day, group 3 was maintained as Withania somnifera (WS) control ( $1 \mathrm{~g} / \mathrm{kg}$ feed) and group 4 was treated with both imidacloprid + Withania somnifera (dose as above). The experiment was carried out for a period of 30 days and the test compound was administered daily by oral gavage. Blood samples were collected on $15^{\text {th }}$ and $30^{\text {th }}$ day for hematological analysis. A significant $(\mathrm{P}<0.05)$ reduction in weekly body weights were observed in group 2. Hematology revealed a significant $(\mathrm{P}<0.05)$ decrease in TEC, Hb, PCV, MCV, MCH and MCHC and increase $(\mathrm{P}<0.05)$ in TLC in group 2. The DLC revealed a significant $(\mathrm{P}<0.05)$ increase in neutrophil count and significant $(\mathrm{P}<0.05)$ decrease in lymphocyte count in group 2. Administration of Withania somnifera along with imidacloprid brought moderate protection in all the above parameters.
\end{abstract}

Keywords: Imidacloprid, body weights, hematology, Withania somnifera

Indiscriminate usage of pesticides in agriculture leading to environmental pollution and several authors have documented the adverse effects of pesticides on nontarget organisms viz. humans, birds, bees, fishes and other aquatic organisms (El-Sayed et al., 2007; Sabra and Mehana, 2015; Gregorc et al., 2018). Imidacloprid (IM) is the first registered neonicotinoid insecticide used to control insect pests on agricultural crops, ectoparasitic arthropods on animals (Hutchinson et al., 2001; Tomizawaand Casida, 2005). It is also used for seed dressing (Felsot, 2001). It is one of the fastest growing and most widely used insecticides in the world (Jeschke and Nauen, 2008). It is having high affinity towards nicotinic acetylcholine receptors (nAch) in insects than mammalian and hence it is selectively toxic to insects (Tomizawa and Casida, 2003). In recent years, the extensive use of IM in agriculture leading to its persistence in soil (Sarkar et al., 2001; Wettstein et al., 2016), water (Sanchez-Bayo et al., 2016), fruits and vegetables (Gervais et al., 2010).

Withania somnifera (WS) is also known as Ashwagandha and is commonly used as an ayurvedic medicine due to its anti-stress, antioxidant, immunomodulating and anti-arthritic activities (Bhattacharya et al., 2001; Bhattacharya et al., 2010). The roots of WS are the most pharmacologically active part of the plant and are known to possess free radical scavenging and antioxidant activity (Shahriar et al., 2013).

How to cite this article: Soujanya, S., Lakshman, M., Madhuri, D. Reddy, A.G. and Rao, S.V.R. (2020). Hematological alterations induced by imidacloprid and ameliorative effect of Withania somnifera in female albino wistar rats. J. Anim. Res., 10(2): 215-220. 
In present study, the toxic effects of imidacloprid and its amelioration with WS in female rats were investigated with special reference to weekly body weights and hematological parameters.

\section{MATERIALS AND METHODS}

\section{Chemicals}

Imidacloprid was procured from Tropical Agrosystem India Pvt. Ltd., Chennai, Tamilnadu and Withania somnifera was obtained from Herboleaf Organic, Haryana, India.

\section{Experimental animals}

Forty-eight (48) female Wistar rats weighing 200-250 $\mathrm{g}$ were procured from Jeeva life sciences, Hyderabad. Before the commencement of study, the rats were allowed to acclimatize to the experimental conditions for ten days. The rats were housed in solid bottom polypropylene cages at RUSKA Labs, Hyderabad and were maintained in controlled environment (Temperature $20-22^{\circ} \mathrm{C}$ ) throughout the course of the experiment. Sterile rice husk was used as a bedding material. All the rats were provided with standard pellet diet (procured from Vyas Labs, Uppal, Hyderabad) and sterile water ad libitum throughout the experimental period. The experiment was conducted according to the guidelines and with prior approval of the Institutional Animal Ethics Committee.

\section{Experimental design}

A total of 48 female rats were divided into four groups comprising of twelve each.

1. Group 1 - Control.

2. Group 2 - Imidacloprid at the rate of $30 \mathrm{mg} / \mathrm{kg} \mathrm{b.wt} /$ day.

3. Group 3 - Withania somnifera at the rate of $1 \mathrm{~g} / \mathrm{kg}$ feed.

4. Group 4 - Imidacloprid + Withania somnifera (30 mg/ $\mathrm{kg} \mathrm{b.wt} /$ day+1 $\mathrm{g} / \mathrm{kg}$ feed).

The test compound was administered daily for a period of 30 days by oral gavage.

\section{Weekly body weights / weight gains}

Individual body weights of all the rats were recorded by using electronic balance on day one and subsequently on $7^{\text {th }}, 14^{\text {th }}, 21^{\text {st }}$ and $28^{\text {th }}$ day of experiment to study the weekly body weight gains.

\section{Hematology}

On $15^{\text {th }}$ and $30^{\text {th }}$ day of experiment, 2 to $3 \mathrm{~mL}$ of blood was collected from retro-orbital plexus with the help of a capillary tube into an anticoagulant coated vaccutainers for hematological examination. Total erythrocyte count (TEC), total leukocyte count (TLC), hemoglobin (Hb) concentration, packed cell volume(PCV), mean corpuscular volume $(\mathrm{MCV})$, mean corpuscular haemoglobin $(\mathrm{MCH})$, mean corpuscular haemoglobin concentration (MCHC) and differential leucocyte count (DLC) were estimated by using automatic whole blood analyzer (Huma count, med source ozone biochemical Pvt. Ltd).

\section{Statistical analysis}

The data obtained were subjected to statistical analysis by applying one way ANOVA using statistical package for social sciences (SPSS) version 16.0. Differences between the means was tested by using Duncan's multiple comparison test and significance level was set at $\mathrm{P}<0.05$ (Snedecor and Cochran, 1994).

\section{RESULTS AND DISCUSSION}

\section{Effect of imidacloprid on weekly body weights}

Significantly higher mean values were recorded in group 1 $(262.17 \pm 0.50,273.20 \pm 0.56,282.75 \pm 0.68$ and $289.83 \pm 0.98)$ and group $3(261.96 \pm 0.79,271.91 \pm 0.47,281.92 \pm 0.65$ and $289.25 \pm 0.91)$ on $7^{\text {th }}, 14^{\text {th }}, 21^{\text {st }}$ and $28^{\text {th }}$ day of experiment respectively than the group $2(256.96 \pm 0.77,264.79 \pm 0.45$, $267.42 \pm 0.42$ and $269.83 \pm 0.42)$ and group $4(259.25 \pm 0.42$, $267.70 \pm 0.35,273.08 \pm 0.42$ and $278.17 \pm 0.66)$. A significant difference was also observed between group 2 and group 4. There was no significant difference between group 1 and group 3 (Fig. 1). 


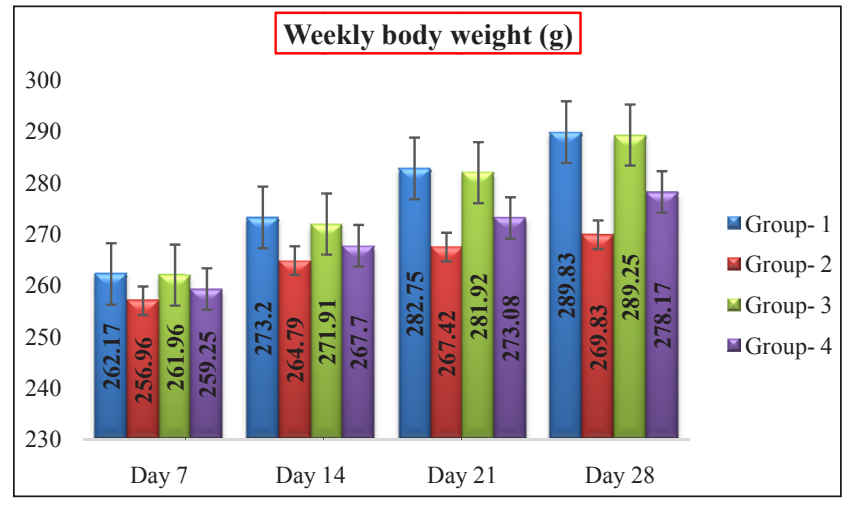

Fig. 1: Effect of oral administration of imidacloprid on weekly body weight in female rats

Results are represented as Mean $\pm \mathrm{SE}$.

\section{Effect of imidacloprid on weekly body weight gain}

A significant $(\mathrm{P}<0.05)$ reduction of body weight gain was observed in group $2(7.33 \pm 0.28,6.33 \pm 0.38,3.17 \pm 0.38$ and $2.42 \pm 0.15)$ on $7^{\text {th }}, 14^{\text {th }}, 21^{\text {st }}$ and $28^{\text {th }}$ day of experiment respectively in comparison to group 1 (11.50 \pm 0.26 , $11.04 \pm 0.23,9.92 \pm 0.33$ and $7.08 \pm 0.69)$. There was a significant $(\mathrm{P}<0.05)$ increase in body weight gain in group $4(8.21 \pm 0.24,8.29 \pm 0.30,4.92 \pm 0.38$ and $5.08 \pm 0.30)$ on $7^{\text {th }}, 14^{\text {th }}, 21^{\text {st }}$ and $28^{\text {th }}$ day of experiment respectively in comparison to group 2 and there was no significant difference between group $3(10.83 \pm 0.32,10.88 \pm 0.27$, $9.75 \pm 0.21$ and $7.33 \pm 0.31$ ) and group 1 (Fig. 2).

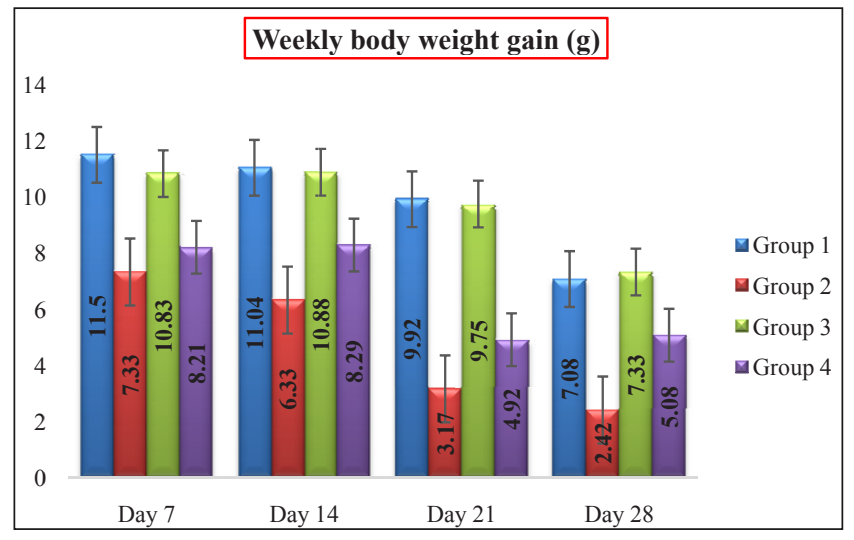

Fig. 2: Effect of oral administration of imidacloprid on weekly body weight gain in female rats

Results are represented as Mean $\pm \mathrm{SE}$.

The reduction in body weight gain in imidacloprid treated rats might be due to decreased food intake as a result of direct toxicity or stress induced by imidacloprid. Anorexia in imidacloprid toxicity might be due to its toxic effect on gastrointestinal tract. These results agree with previous workers (Bhardwaj et al., 2010; Kapoor et al., 2011; Bagri et al., 2013; Arfat et al., 2014; Mehmood et al., 2017; Hassan et al., 2019).

\section{Hematology}

Total erythrocyte count (TEC): A significant $(\mathrm{P}<$ $0.05)$ decrease in TEC values were observed in group 2 in comparison to normal control. In group 4, there was a significant $(\mathrm{P}<0.05)$ increase in TEC values in comparison to group 2 and there was no significant difference between groups 1 and 3 on day 15, and a similar trend was observed on day 30 of experiment (Table 1).

Total Leucocyte Count (TLC): A significant $(\mathrm{P}<0.05)$ increase in TLC values were observed in group 2 in comparison to normal control. In group 4 , there was a significant $(\mathrm{P}<0.05)$ decrease in TLC values in comparison to group 2 and there was no significant difference between groups 1 and 3 on day 15, and a similar trend was observed on day 30 of experiment (Table 1).

Hemoglobin $(\mathbf{H b})$ : A significant $(\mathrm{P}<0.05)$ reduction in $\mathrm{Hb}$ concentration was observed in group 2 in comparison to normal control and there was no significant difference between groups 1, 3 and 4 on day 15, and a similar trend was observed on day 30 of experiment (Table 1).

Packed Cell Volume (PCV): A significant $(\mathrm{P}<0.05)$ decrease in PCV values were observed in group 2 in comparison to normal control. In group 4 , there was a significant $(\mathrm{P}<0.05)$ increase in $\mathrm{PCV}$ values in comparison to group 2 and there was no significant difference between groups 1 and 3 on day 15, and a similar trend was observed on day 30 of experiment (Table 1).

Mean Corpuscular Volume (MCV): A significant ( $\mathrm{P}<$ $0.05)$ decrease in $\mathrm{MCV}$ values were observed in group 2 in comparison to normal control. In group 4, there was a significant $(\mathrm{P}<0.05)$ increase in $\mathrm{MCV}$ values in comparison to group 2 and there was no significant difference between groups 1 and 3 on day 15, and a similar trend was observed on day 30 of experiment (Table 1).

Mean Corpuscular Hemoglobin (MCH): A significant $(\mathrm{P}<0.05)$ decrease in $\mathrm{MCH}$ values were observed in 
Table 1: Effect of oral administration of imidacloprid on hematological parameters in female rats

\begin{tabular}{|c|c|c|c|c|c|c|c|c|}
\hline & Group 1 & & Group 2 & & Group 3 & & Group 4 & \\
\hline & Day 15 & Day 30 & Day 15 & Day 30 & Day 15 & Day 30 & Day 15 & Day 30 \\
\hline $\begin{array}{l}\text { TEC } \\
\text { (millions/ } \mu 1)\end{array}$ & $11.03 \pm 0.31^{\mathrm{a}}$ & $10.88 \pm 0.20^{\mathrm{a}}$ & $8.38 \pm 0.29^{c}$ & $8.12 \pm 0.23^{c}$ & $11.02 \pm 0.15^{\mathrm{a}}$ & $10.78 \pm 0.22^{\mathrm{a}}$ & $9.73 \pm 0.07^{b}$ & $9.33 \pm 0.26^{\mathrm{b}}$ \\
\hline $\begin{array}{l}\text { TLC } \\
\text { (thousands/ } \mu 1 \text { ) }\end{array}$ & $9.31 \pm 0.40^{\mathrm{c}}$ & $9.73 \pm 0.22^{\mathrm{c}}$ & $13.18 \pm 0.23^{\mathrm{a}}$ & $14.92 \pm 0.30^{\mathrm{a}}$ & $9.45 \pm 0.22^{\mathrm{c}}$ & $9.67 \pm 0.54^{c}$ & $11.92 \pm 0.26^{\mathrm{b}}$ & $13.03 \pm 0.32^{b}$ \\
\hline $\mathrm{Hb}(\mathrm{g} / \mathrm{dL})$ & $16.70 \pm 0.18^{\mathrm{a}}$ & $16.17 \pm 0.30^{\mathrm{a}}$ & $14.95 \pm 0.36^{\mathrm{b}}$ & $13.87 \pm 0.42^{\mathrm{b}}$ & $16.85 \pm 0.42^{\mathrm{a}}$ & $16.32 \pm 0.18^{a}$ & $16.17 \pm 0.50^{\mathrm{a}}$ & $15.88 \pm 0.20^{\mathrm{a}}$ \\
\hline PCV (\%) & $64.32 \pm 0.65^{\mathrm{a}}$ & $65.12 \pm 0.62^{\mathrm{a}}$ & $56.65 \pm 0.50^{\mathrm{c}}$ & $55.55 \pm 0.65^{\mathrm{c}}$ & $63.37 \pm 0.53^{\mathrm{a}}$ & $64.22 \pm 0.52^{\mathrm{a}}$ & $58.83 \pm 0.31^{b}$ & $59.97 \pm 0.75^{\mathrm{b}}$ \\
\hline MCV (fl) & $63.03 \pm 0.36^{\mathrm{a}}$ & $62.88 \pm 0.35^{\mathrm{a}}$ & $56.83 \pm 0.20^{\mathrm{c}}$ & $56.56 \pm 0.25^{\mathrm{c}}$ & $62.30 \pm 0.38^{\mathrm{a}}$ & $61.98 \pm 0.35^{\mathrm{a}}$ & $60.22 \pm 0.55^{\mathrm{b}}$ & $59.83 \pm 0.60^{\mathrm{b}}$ \\
\hline $\mathrm{MCH}$ (pg) & $22.07 \pm 0.23^{\mathrm{a}}$ & $23.15 \pm 0.24^{\mathrm{a}}$ & $19.27 \pm 0.28^{b}$ & $19.83 \pm 0.19^{b}$ & $21.38 \pm 0.37^{\mathrm{a}}$ & $22.50 \pm 0.22^{\mathrm{a}}$ & $19.52 \pm 0.33^{b}$ & $20.33 \pm 0.30^{b}$ \\
\hline $\mathrm{MCHC}(\mathrm{g} / \mathrm{dL})$ & $33.67 \pm 0.31^{\mathrm{a}}$ & $32.62 \pm 0.46^{\mathrm{a}}$ & $29.50 \pm 0.13^{\mathrm{c}}$ & $28.98 \pm 0.29^{c}$ & $33.22 \pm 0.20^{\mathrm{a}}$ & $33.32 \pm 0.32^{\mathrm{a}}$ & $31.48 \pm 0.40^{\mathrm{b}}$ & $30.65 \pm 0.26^{\mathrm{b}}$ \\
\hline
\end{tabular}

Values are mean $\pm \mathrm{SE}(\mathrm{n}=6)$, One way ANOVA, Means with different superscripts in a row differ significantly $(\mathrm{P}<0.05)$.

Table 2: Effect of oral administration of imidacloprid on differential leucocyte count (\%) in female rats

\begin{tabular}{lllllllll}
\hline \multirow{2}{*}{ Group } & \multicolumn{2}{c}{ Lymphocyte } & \multicolumn{2}{c}{ Neutrophil } & \multicolumn{2}{c}{ Monocyte } & \multicolumn{2}{c}{ Eosinophil } \\
\cline { 2 - 9 } & Day 15 & Day 30 & Day 15 & Day 30 & Day 15 & Day 30 & Day 15 & Day 30 \\
\hline Group- 1 & $81.67 \pm 0.62^{\mathrm{a}}$ & $81.33 \pm 0.92^{\mathrm{a}}$ & $15.00 \pm 0.37^{\mathrm{c}}$ & $15.33 \pm 0.62^{\mathrm{c}}$ & $1.83 \pm 0.31^{\mathrm{a}}$ & $2.83 \pm 0.61^{\mathrm{a}}$ & $1.50 \pm 0.22^{\mathrm{a}}$ & $0.50 \pm 0.23^{\mathrm{a}}$ \\
Group- 2 & $73.17 \pm 0.60^{\mathrm{c}}$ & $72.33 \pm 0.99^{\mathrm{c}}$ & $23.50 \pm 0.62^{\mathrm{a}}$ & $24.00 \pm 0.73^{\mathrm{a}}$ & $2.00 \pm 0.26^{\mathrm{a}}$ & $2.50 \pm 0.57^{\mathrm{a}}$ & $1.33 \pm 0.21^{\mathrm{a}}$ & $1.17 \pm 0.30^{\mathrm{a}}$ \\
Group- 3 & $82.00 \pm 0.58^{\mathrm{a}}$ & $81.17 \pm 0.79^{\mathrm{a}}$ & $15.17 \pm 0.31^{\mathrm{c}}$ & $15.67 \pm 0.43^{\mathrm{c}}$ & $1.67 \pm 0.33^{\mathrm{a}}$ & $2.17 \pm 0.55^{\mathrm{a}}$ & $1.17 \pm 0.31^{\mathrm{a}}$ & $1.00 \pm 0.36^{\mathrm{a}}$ \\
Group- 4 & $76.83 \pm 0.48^{\mathrm{b}}$ & $76.50 \pm 0.50^{\mathrm{b}}$ & $20.17 \pm 0.40^{\mathrm{b}}$ & $20.50 \pm 0.35^{\mathrm{b}}$ & $2.17 \pm 0.40^{\mathrm{a}}$ & $2.33 \pm 0.49^{\mathrm{a}}$ & $0.83 \pm 0.17^{\mathrm{a}}$ & $0.67 \pm 0.22^{\mathrm{a}}$ \\
\hline
\end{tabular}

Values are Mean \pm SE $(n=6)$; One way ANOVA, Means with different superscripts in a column differ significantly at $\mathrm{P}<0.05$.

group 2 in comparison to normal control. There was no significant difference between groups 1, 3 and groups 2 and 4 on day 15 , and a similar trend was observed on day 30 of experiment (Table 1).

Mean Corpuscular Hemoglobin Concentration (MCHC): A significant $(\mathrm{P}<0.05)$ decrease in $\mathrm{MCHC}$ values were observed in group 2 in comparison to normal control. In group 4 , there was a significant $(\mathrm{P}<0.05)$ increase in $\mathrm{MCHC}$ values in comparison to group 2 and there was no significant difference between groups 1 and 3 on day 15 , and a similar trend was observed on day 30 of experiment (Table 1).

Differential leucocyte count (DLC): A significant $(\mathrm{P}<$ 0.05 ) increase in neutrophil count was observed in group 2 in comparison to normal control. In group 4, there was a significant $(\mathrm{P}<0.05)$ decrease in neutrophil count in comparison to group 2 and there was no significant difference between groups 1 and 3 on day 15, and a similar trend was observed on day 30 of experiment (Table 2).
A significant $(\mathrm{P}<0.05)$ decrease in lymphocyte count was observed in group 2 in comparison to normal control. In group 4 , there was a significant $(\mathrm{P}<0.05)$ increase in lymphocyte count in comparison to group 2 and there was no significant difference between groups 1 and 3 on day 15 , and a similar trend was observed on day 30 of experiment (Table 2).

There was no significant difference in mean values of monocyte and eosinophil count in groups 1, 2, 3 and 4 on day 15, and a similar trend was observed on day 30 of experiment (Table 2).

The decrease in hemoglobin concentration in imidacloprid treated rats might be due to reduced synthesis of hemoglobin which require iron and it is generally obtained from stored ferritin or from the diet. In imidacloprid toxicity the feed intake is reduced hence there is reduced iron intake from the diet which resulted in iron deficiency. Reduction of hemoglobin content may further cause decrease in erythrocyte count and hematocrit values. The decreased 
hematological values viz., TEC, $\mathrm{Hb}, \mathrm{PCV}, \mathrm{MCV}, \mathrm{MCH}$ and MCHC may also be due to toxic effects of imidacloprid on bonemarrow due to increased levels of reactive oxygen species which cause stress and effect erythropoiesis in bonemarrow or due to its toxic effect on liver, kidney which play role in extramedullary hematopoiesis and synthesis of erythropoietin by respective organs. Increased TLC may be related to an increase in total neutrophils count which might be due to activation of leucopoiesis by imidacloprid. These findings are in accordance with earlier researchers (Mohany et al., 2011; Ravikanth et al., 2017; Badawy et al., 2018). In the present study, administration of Withania somnifera provided moderate protection in all the above parameters. It might be due to its free radical scavenging and anti-stress properties.

\section{CONCLUSION}

The current study revealed that exposure to imidacloprid (30 $\mathrm{mg} / \mathrm{kg}$ body weight/day) in female rats resulted in a significant decrease in body weight gain and marked alterations in hematological parameters. However, Withania somnifera is a potent antioxidant which ameliorated the toxic effects induced by imidacloprid to certain extent.

\section{ACKNOWLEDGEMENTS}

The Authors are thankful to the College of Veterinary Science, PVNRTVU, Rajendranagar, Hyderabad for providing the facilities to carry out the present research work.

\section{REFERENCES}

Arfat, Y., Mahmood, N., Tahir, M.U., Rashid, M., Anjum, S., Zaho, F., Li, D.J., Sun, Y.L., Hu, L., Zhihao, C., Yin, C., Shang, P. and Qian, A.R. 2014. Effect of imidacloprid on hepatotoxicity and nephrotoxicity in male albino mice. Toxicol. Rep., 1: 554-561.

Badawy, M.H., Ahmed, N.S. and Attia, A.M. 2018. Sub-acute oral toxicity of imidacloprid and fipronil pesticide mixture in male albino rats, biochemical and reproductive toxicity evaluation. J. Mater. Environ. Sci., 9(8): 2431-2437.

Bagri, P., Kumar, V., Sikka, A.K. and Punia, J.S. 2013. Preliminary acute toxicity study on imidacloprid in swiss albino mice. Vet. World., 6(12): 955-959.

Bhardwaj, S., Srivastava, M.K., Upasana, K. and Srivastava, L.P.
2010. A 90 days oral toxicity of imidacloprid in female rats: morphological, biochemical \& histopathological evaluation. Food Chem. Toxicol., 48: 1185-1190.

Bhattacharya, A., Ghosal, S. and Bhattacharya, S.K. 2001. Antioxidant effect of Withania somnifera glycowithanolides in chronic foot shock stress induced perturbations of oxidative free radical scavenging enzymes and lipid peroxidation in rat frontal cortex and striatum. J. Ethnopharmacol., 74: 1-6.

Bhattacharya, A., Ramanathan, M., Ghosal S. and Bhattacharya, S.K. 2010. Effect of Withania somnifera glycowithanolides on iron-induced hepatotoxicity in rats. Phytother. Res., 14(7): $568-570$.

El-Sayed, Y.S., Saad, T.T. and El-Bahr, S.M. 2007. Acute intoxication of deltamethrin in monosex Nile tilapia, Oreochromis niloticus with special reference to the clinical, biochemical and hematological effects. Environ. Toxicol. Pharmacol., 24(3): 212-17.

Felsot, A. 2001. Admiring risk reduction. Does imidacloprid have what it takes? Agrichemical and Environ. News, 186: 1-12.

Gervais, J.A., Luukinen, B., Buhl, K. and Stone, D. 2010. Imidacloprid general fact sheet; National Pesticide Information Center, Oregon State University Extension Services.

Gregorc, A., Alburaki, M., Rinderer, N., Sampson, B., Knight, P.R., Karim, S. and Adamczyk, J. 2018. Effects of coumaphos and imidacloprid on honeybee (Hymenoptera: Apidae) lifespan and antioxidant gene regulations in laboratory experiments. Sci. Rep., 8: 1-13.

Hassan, A.M.S., El-Ela, A. and Abdel-Aziz, A.M. 2019. Investigating the potential protective effects of natural product quercetin against imidacloprid induced biochemical toxicity and DNA damage in adult rats. Toxicol. Rep., 6: 727735 .

Hutchinson, M.J., Jacobs, D.E. and Mencke, N. 2001. Establishment of the cat flea (Ctenocephalides felis) on the ferret (Mustela putorius furo) and its control with imidacloprid. Med. Vet. Entomol., 15(2): 212-214.

Jeschke, P. and Nauen, R. 2008. Neonicotinoids from zero to hero in insecticide chemistry. Pest Manag. Sci., 64: 10841098.

Kapoor, U., Srivastava, M.K. and Srivastava, L.P. 2011. Toxicological impact of technical imidacloprid on ovarian morphology, hormones and antioxidant enzymes in female rats. Food. Chem. Toxicol., 49: 3086-3089.

Mehmood, T., Saeed, M., Ahmad, M.M., Ikram, M.S., Siddique, F. and Tabassam, Q. 2017. Effect of imidacloprid (insecticide) on serum biochemical parameters and degenerative lesions in male rat's liver. Sind. Univ. Res. J. (Sci. Ser.), 49(3): 605-612. 
Mohany, M., Badr, G., Refaat, I. and EI-feki, M. 2011. Immunological and histological effects of exposure to imidacloprid insecticide in male albino rats. Afr. J. Pharm. Pharmaco., 5(18): 2106-2114.

Ravikanth, V., Lakshman, M., Madhuri, D. and Kalakumar, B. 2017. Hematological alterations in broilers administered with imidacloprid and spinosad and its amelioration with vitamin E and silymarin. Int. J. Curr. Microbiol. Appl. Sci., 6(4): 496500 .

Sabra, F.S. and Mehana, E.E. 2015. Pesticides toxicity in fish with particular reference to insecticides. Asian J. Agr. Food Sci., 3(1): 40-60.

Sanchez-Bayo, F., Goka, K. and Hayasaka, D. 2016. Contamination of the aquatic environment with neonicotinoids and its implication for ecosystems. Front. Environ. Sci., 4: $1-14$.

Sarkar, M.A., Roy, S., Kole, R.K. and Chowdhury, A. 2001. Persistence and metabolism of imidacloprid in different soils of West Bengal. Pest Manag. Sci., 57(7): 598-602.
Shahriar, M., Hossain, M.I., Sharmin, F.A., Akhter, S., Haque, M.A. and Bhuiyan, M.A. 2013. In vitro antioxidant and free radical scavenging activity of Withania somnifera root. IOSR. J. Pharm., 3(2): 38-47.

Snedecor, G.W. and Cochran, G. 1994. Statistical methods, $8^{\text {th }}$ edition, IOWA State University Press, Amer, IOWA, USA.

Tomizawa, M. and Casida, J.E. 2003. Selective toxicity of neonicotinoids attributable to specificity of insect and mammalian nicotinic receptors. Annu. Rev. Entomol., 48: 339-364.

Tomizawa, M., and Casida, J.E. 2005. Neonicotinoid insecticide toxicology: Mechanisms of selective action. Annu. Rev. Pharmacol. Toxicol., 45: 247-268.

Wettstein, F.E., Kasteel, R., Delgado, G.M.F., Hanke, I., Huntscha, S., Balmer, M.E., Poiger, T. and Bucheli, T.D. 2016. Leaching of the neonicotinoids thiamethoxam and imidacloprid from sugar beet seed dressings to subsurface tile drains. J. Agr. Food. Chem., 64(33): 6407-6415. 